\title{
Corpuscular Hemoglobin Concentration Distribution Width
}

National Cancer Institute

\section{Source}

National Cancer Institute. Corpuscular Hemoglobin Concentration Distribution Width. NCI Thesaurus. Code C139068.

A measurement of the standard deviation of hemoglobin concentrations in individual red blood cells, calculated as the standard deviation of hemoglobin content divided by the mean hemoglobin content. 